ОСОБЛИВОСТІ ПІДГОТОВКИ МАЙБУТНІХ УЧИТЕЛІВ ДО ВИКОРИСТАННЯ ІНФОРМАЦІЙНО-КОМУНІКАЦІЙНИХ ТЕХНОЛОГІЙ В ОСВІТНЬОМУ ПРОЦЕСІ

\title{
FEATURES OF PREPARATION OF FUTURE TEACHERS FOR THE USE OF INFORMATION AND COMMUNICATION TECHNOLOGIES IN THE EDUCATIONAL PROCESS
}

УДК 378.013

DOI https://doi.org/10.32843/2663$6085 / 2021 / 37.63$

\author{
Яновський А.О., \\ канд. пед. наук, \\ доцент кафедри прикладної \\ математики та інфрорматики \\ Південноукраїнського національного \\ педагогічного університету \\ імені К.Д. Ушинського \\ Яновська Л.Г., \\ канд. пед. наук, \\ доцент кафедри всесвітньої історії \\ та методології науки \\ Південноукраїнського національного \\ педагогічного університету \\ імені К.Д. Ушинського
}

у статті розглядається питання особливості підготовки майбутніх учителів до використання інфоормаційно-комунікаційних технологій в освітньому процесі. Метою дослідження $є$ теоретичне обгрунтування та вивчення шляхів покращення змісту навчання майбутніх учителів щодо використання IKT в освітньому процесі. Була проаналізована література 3 проблематики та визначені принципи добору програмних продуктів, які будуть корисні майбутнім учителям. У статті розкривається зміст робочої програми інфоорматичних дисциплін для майбутніх учителів, особливості використання хмарних сервісів у майбутній профресійній діяльності. Під час вивчення курсу розглядаються такі аспекти, як: архітектура хмарних обчислень; характеристики хмарних технологій; моделі хмарного розміщення; класиорікація моделей обслуговування: переваги та недоліки. Але найбільш грунтовно приділяється увага класифрікації хмарних сервісів та їх використанню в освітньому прочесі. Далі ми пропонуємо вивчення особливостей створення інсрографьки за допомогою сучасних інтернет-сервісів. Основними завданнями під час вивчення цієї теми є: суть, мета та мова візуалізаціі даних; роль інфрограсріки в профресійній діяльності вчителя; технологія візуалізації статичної інсоормації засобами інсрограсфіки; засоби web-2.0 для створення статичноі та динамічної інфоографріки. Наступний блок тем розкриває програмні засоби для найбільш ефрективної візуалізації навчального матеріалу. Ми пропонуємо для презентування матеріалу створення презентацій нелінійної структури засобами Рrezi. Також ми пропонуємо розглянути особливості створення та публікації відео-презентацій (Скрайбінг презентацій). Наступна тема пов'язана з блоком візуалізації, де розглядаються особливості створення ментальних карт та інтерактивних плакатів засобами хмарних сервісів. Наступний напрям - че використання сервісів Web 2.0 для створення дидактичних інтерактивних матеріалів та комп'ютерних засобів контролю знань. Також вивчалися теми створення вебінарів та вивчення особливостей створення аудіо- та відеокліпів навчального призначення. Останнім кроком було вивчення особливостей створення та оформлення блогу у мережі Інтернет.

Ключові слова: інфрормаційно-комунікаційні технології, інсрорматичні дисципліни, хмарні технології, інформатична компетентність, освіma.

The article considers the peculiarities of training future teachers to use information and communication technologies in the educational process. The purpose of the study is to theoretically substantiate and study ways to improve the content of teaching future teachers to use ICT in the educational process. The literature on the issues was analyzed and the principles of selection of software products that will be useful for future teachers were determined. The article proposes the following content of the work program of computer science disciplines for future teachers. Features of using cloud services in future professional activities. During the study of the topic such aspects are considered as: architecture of cloud computing; characteristics of cloud technologies; cloud placement models; classification of service models; Advantages and disadvantages. But the most thorough attention is paid to the classification of cloud services and their use in the educational process. The next topic we offer is the study of the peculiarities of creating infographics with the help of modern Internet services. During the study of the topic are considered: the essence, purpose and language of data visualization; the role of infographics in the professional activities of teachers; technology of visualization of static information by means of infographics; web-2.0 tools for creating static and dynamic infographics. The next block of topics reveals software tools for the most effective visualization of educational material. We offer for presentation of material of creation of presentations of nonlinear structure by means of Prezi. We also propose to consider the features of creating and publishing video presentations (Scribing presentations). The next topic related to the visualization unit is the features of creating mental maps and interactive posters by means of cloud services. The next direction is the use of Web 2.0 services to create didactic interactive materials and computer tools for knowledge control. The topics of creating webinars and studying the peculiarities of creating audio and video clips for educational purposes were also studied. The last step was to study the peculiarities of creating and designing a blog on the Internet.

Key words: information and communication technologies, information disciplines, cloud technologies, information competence, education.
Постановка проблеми у загальному вигляді. У сучасному світі роль інфрормаційно-комунікаційних технологій значно зростає у всіх сферах життя людини, зокрема в освіті. Перехід до дистанційної освіти під час пандемії показав недостатню готовність учителів до використання всього різноманіття інформаційно-комунікаційних технологій в організації освітнього процесу дистанційного формату. І якщо розглядати процес дистанційної освіти лише через призму організації онлайн-консреренції, то цей процес з часом налагодився. Але якщо розглядати організацію дистанційного навчання як створення освітнього середовища, де можна використати всі можливості IKT для 
покращення якості освітнього процесу, то тут $є$ багато прогалин, оскільки вчителі не знайомі зі всім різноманіттям хмарних сервісів та програмних засобів, що дозволяють створити дружнє інфрормаційне освітнє середовище, в якому можна не лише спілкуватися засобами онлайн-конференції, а також розміщувати дидактичні наробки, наприклад, у власному блозі, які будуть включати ігрові, інтерактивні засоби для активізації пізнавального інтересу та пізнавальної активності учнів. Це можна досягти завдяки хмарним сервісам та програмним засобам, що спрямовані на розробку дидактичного контенту, як-от створення онлайн-вікторин, онлайн-кросвордів, онлайн-ребусів тощо. Тому для підготовки майбутніх учителів ми підготували добірку хмарних сервісів та локальних програмних засобів, спрямованих на підвищення ефективності використання ІКТ в освітньому процесі.

Аналіз останніх досліджень і публікацій. Вивченням особливостей використання інформаційно-комунікаційних технологій в освіті займалися такі вчені, як В. Биков, А. Гуржій, М. Жалдак, М. Кадемія, С. Литвинова, І. Малицька, Н. Морзе, І. Підласий, О. Пєхота, О. Спірін, Т. Тарнавська, Ю. Триус та інші. Проблему підготовки вчителів до використання IКТ в освітньому процесі висвітлювали у своїх працях С. Гунько, О. Майборода, Й. Ринквід, О. Співаковський. Проблему фрормування інорормаційної культури вчителів розглядали Р. Гуревич, М. Жалдак, А. Коломієць, Н. Морзе. Особливості використання хмарних сервісів у освітньому процесі досліджували Т. Бондаренко Т. Вакалюк, О. Романовський, І. Шахіна, М. Шишкіна.

Виділення не вирішених раніше частин загальної проблеми. Вивчаючи науково-педагогічну літературу стосовно особливостей навчання майбутніх учителів використанню ІКТ в освітньому процесі, можна дійти висновку, що швидкі темпи розвитку технічних можливостей комп'ютерної техніки та Інтернету дозволяють створювати більш потужні програмні засоби, покращувати наявні, створювати нові хмарні сервіси тощо. Це призводить до швидкого старіння змісту, що стосується прикладної частини використання програмних засобів. Тому завжди є необхідність оновлювати зміст інформатичних дисциплін у закладах вищої освіти, покликаних підготувати майбутніх учителів до використання IKT у майбутній професійній діяльності.

Метою статті $€$ теоретичне обґрунтування та вивчення шляхів покращення змісту навчання майбутніх учителів використанню ІКТ в освітньому процесі.

Виклад основного матеріалу. Основними завданнями дослідження було вивчення сучасних програмних продуктів, які можна використовувати в дидактичних цілях майбутнім учителям, онов- лення змісту програм інорорматичних дисциплін відповідно до потреб освітнього процесу.

Як зазначає 3. Мотилькова, не всі вчителі готові до використання ІКТ в освітньому процесі. Поглиблення знань учителя зі свого предмету і підвищення його професійної майстерності - це головне для навчального закладу, бо навіть самий суперсучасний комп'ютер за наявності блискучих навчальних продуктів без учителя-прооресіонала залишиться просто машиною. Тому, вивчаючи комп'ютер, учитель-предметник не повинен освоювати щось, що виходить далеко за рамки його предмету. Учитель повинен бути майстром у своїй справі, у своєму предметі, а комп'ютер і програми повинні слугувати додатком, полегшенням, наочністю під час проведення уроків [6].

На думку Н. Морзе, надійною основою та невіддільною частиною процесу впровадження інноваційних педагогічних технологій $€$ формування інформатичних компетентностей учителів, викладачів, співробітників та керівників закладів освіти. Саме від неї залежить ефективність освітнього процесу. Причому складники таких інформатичних компетентностей весь час мають оновлюватися залежно від об'єктивних змін, які відбуваються в освіті, суспільстві та ринку освітніх послуг [5]. На нашу думку, на сучасному етапі розвитку IKT фрормування інорорматичної компетентності - це здатність використовувати Інтернет-сервіси, які належать до Веб 2.0. Це зумовлено тим, що розвиток хмарних сервісів досить динамічно змінюється, пропонуються нові продукти та покращуються старі, саме зміст використання інтернет сервісів Веб 2.0 потребує постійного оновлення, а добір сервісів, на основі яких можна буде сформувати необхідну компетентність, $€$ важливим. В дослідженні ми визначили головні принципи добору програмних продуктів, які майбутні учителі зможуть використовувати в професійній діяльності:

- корисності, тобто дидактичні можливості програмних продуктів, що вивчаються, повинні співпадати 3 цілями майбутньої професійної діяльності;

- доступності програмного продукту в аспекті технічних вимог, легкості у використанні (віддається перевага хмарним технологіям);

- відповідності реаліям сьогодення, сучасна яскрава візуалізація, спрямована на захоплення уваги, викликання інтересу до контенту, створення емоційно-позитивного забарвлення контенту.

На нашу думку, необхідно особливу увагу приділити вивченню майбутніми вчителями особливостей використання хмарних сервісів у майбутній профресійній діяльності.

У наукових працях М. Шишкіної хмарні сервіси - це сервіси, призначені для того, щоб робити доступним для користувача прикладне програмне забезпечення, простір для зберігання даних та обчислювальні потужності через Інтернет. 
Хмарні сервіси застосовують для того, щоб надавати користувачеві електронні освітні ресурси, що складають змістовне наповнення хмарно орієнтовного середовища, також забезпечити процеси створення і постачання освітніх сервісів [11]. Завдяки цим властивостям можливо створити хмарно орієнтоване освітньо-наукове середовище, у якому передбачено використання технології хмарних обчислень для забезпечення IKT-підтримування його фрункціонування і розвитку [11].

Надалі ми розглядали такі теми, як: архітектура хмарних обчислень; характеристики хмарних технологій; моделі хмарного розміщення; класифікація моделей обслуговування. Також визначимо переваги та недоліки цих сервісів. Але найбільш ґрунтовно приділялася увага класифрікації хмарних сервісів та їх використанню в освітньому процесі.

Наступна тема, яку ми пропонуємо, - це вивчення особливостей створення інфографіки за допомогою сучасних інтернет-сервісів.

Значенню наочності та візуалізації інфрормації в навчальному процесі присвячено багато праць, доведено, що використання наочності покращує сприйняття матеріалу і робить його більш цікавим. Так, ще С. Рубінштейн зазначав, що роль зорових відчуттів у пізнанні світу особливо велика. Вони доставляють людині виключно багаті і тонко диференційовані дані величезного діапазону. Зір дає нам найбільш досконале, справжнє сприйняття предметів. Зорові відчуття найбільш диференційовані від афективності, в них особливо сильний момент чуттєвого споглядання. Зорові сприйняття $€$ найбільш «опредмеченими». Саме тому вони мають дуже велике значення для пізнання і для практичної дії (С. Рубінштейн).

У своїх дослідженнях Л. Білоусова визначає візуалізацію як прийоми і методи подання інформації у вигляді, зручному для зорового спостереження. При цьому йдеться про перетворення інорормації, якому вона піддається незалежно від того, була вона чи не була спочатку представлена у вигляді, доступному для сприйняття зором. Авторка зазначає, що доцільність використання візуалізації навчальної інфрормації продиктована насамперед необхідністю її подання у вигляді, найбільш відповідному новим потребам сучасного покоління учнів. Характеризуючи це покоління, кажуть про нову культуру сприйняття інфрормації, про мислення нового типу, яке фрормується як реакція на стрімке зростання інформаційних потоків, переважно у візуальній фрормі, на високу фррагментарність, велику різноманітність і повну різнорідність інфрормації, що надходить [1]. На нашу думку, саме інфрографріка дає змогу досягти мети привернення уваги учнів до контенту, враховуючи вищезазначене.

Таким чином, на думку вченої Л. Білоусової, візуалізація навчальної інформації: полегшує сприйняття навчальної інфрормації учнями, представляючи її з урахуванням і відповідно до їх когнітивних особливостей; сприяє фрормуванню правильних уявлень школярів про об'єкти вивчення, позбавляючи від необхідності в подальшому коригувати початкові хибні уявлення; дає можливість сконцентрувати увагу учнів на головних смислових елементах навчального матеріалу, виділяючи їх у зоровому образі і одночасно фрільтруючи другорядні і зайві деталі; дозволяє інтенсифікувати навчальний процес за рахунок використання економічного за обсягом і часом подання навчального матеріалу в образному вигляді; активізує різні види мислення і пам'яті учнів; сприяє кращому включенню нових знань у систему раніше придбаних, а також їх засвоєнню і запам'ятовуванню учнями; розвиває пізнавальний інтерес учнів; дає можливість створити позитивний емоційний фрон на уроці; полегшує реалізацію міжпредметних зв'язків у навчанні [1].

Науковець І. Шахіна поділяє інфрографріку на три категорії: графріки та таблиці; логічні схеми та реконструкції; графрічні розповіді. Також авторка зазначає, що технологія інфрографріки виходить 3 того, що зображення роблять дані більш привабливими для їх сприйняття, сприяють їх ефективному запам'ятовуванню, підвищують їх переконливість [10].

У своєму дослідженні І. Шахіна узагальнює цілі педагога під час роботи з інфографікою, до них вона відносить: викликати емоції та передати суть через візуальний образ, тим самим привертаючи увагу до потрібного об'єкту, важливої проблеми тощо; допомогти учню / студенту творчо подати результати свого власного дослідження; залучити учнів / студентів до колективної творчості з використанням технологій Веб 2.0 (викладачі можуть організовувати мережеві проєкти, в ході яких студенти мають можливість під їх керівництвом створювати інфрографрічний контент) [10].

Під час вивчення теми розглядаються: суть, мета та мова візуалізації даних; роль інфографріки в професійній діяльності вчителя; технологія візуалізації статичної інформації засобами інфографріки; засоби web-2.0 для створення статичної та динамічної інфрографріки.

Наступний блок тем розкриває програмні засоби для найбільш ефективної візуалізації навчального матеріалу.

Ми пропонуємо для презентування матеріалу використовувати не лише відомі програмні засоби, такі як MS PowerPoint, але й створювати презентації нелінійної структури засобами Prezi.

Хмарний сервіс Prezi - це інструмент для створення презентацій у нелінійній структурі. На відміну від класичних покрокових аналогів, у середовищі Prezi робота здійснюється не з окремими кадрами оболонки, а з усією робочою областю, на 
якій розміщується необхідний контент у вигляді заголовків, текстових блоків, стікерів, геометричних фрігур, картинок, відеороликів, звукових доріжок. Тобто засіб Prezi має суцільне полотно, на якому зосереджений увесь процес роботи зі створення презентації. На ньому відбувається переміщення, приближення і віддалення уявної камери. Завдяки цьому глядачі інтуїтивно розуміють, на якому рівні узагальнення і деталізації вони знаходяться у певний момент. Попри це, єдиний образ усієї презентації дозволяє лектору (вчителю) в будь-який момент виступу перейти до потрібного кадру доповіді [3].

Пропонуються такі варіанти виступів, які варто оформити за допомогою технології Prezi: 1) причинно-наслідковий зв'язок; 2) асоціативна карта. Спочатку розглядаються ключові поняття, а потім висвітлюється асоціативний ряд доповнень, які й формують загальний вигляд презентації. [3].

Під час вивчення теми розглядаються: особливості використання хмарного сервісу Prezi.com у майбутній професійній діяльності; налаштування анімації; робота з текстом, зображеннями, відео; публікація презентації в мережах, створення посилання, спільна робота.

Також ми пропонуємо розглянути особливості створення та публікації відео-презентацій (Скрайбінг презентацій).

Науковці Л. Білоусова та Н. Житєньова зазначають, що провідним ефектом скрайбінгу $\epsilon$ захват уваги аудиторії специфічними графічними образами, що створюються тут і зараз, виразно акцентуючи на заздалегідь визначених ключових моментах матеріалу, що подається, - ідеях, особливостях, відмітних рисах тощо, тобто саме на тому головному, що потрібно сприйняти, усвідомити, запам'ятати. Варто підкреслити, що сучасні учні звикли до швидких темпів життя, вони непосидючі, їх увагу важко сконцентрувати на тривалий час. Скрайбінг виступає зручним інструментом не тільки для викладу навчального матеріалу. Новизна й привабливість цієї технології дає змогу на іiї основі організовувати самостійну роботу учнів, спрямовану на опрацювання ними вивченого матеріалу, відтворення власного ставлення до об'єкта навчання. Використання скрайбінгу дає змогу надати такій роботі привабливості для учнів, забезпечити її творчий характер, сприяти зацікавленню школярів у набутті нових предметних знань і технологічних умінь [2].

На нашу думку, для створення відеопрезентацій $з$ ефректом скрайбінгу доцільно використовувати хмарний сервіс Powtoon. Цей сервіс дає змогу створювати слайди, на яких можна розміщувати сцену та анімованих персонажів, також налаштовувати додаткову анімацію, що перетворюється на мультиплікацію з сюжетом заданої тематики. Така відео-презентація викликає жвавий інтересу в учнів, захоплює увагу та передає великі обсяги інфрормації у стислому форматі.

На заняттях розглядаються: розробка скрайбінг-презентацій засобами Powtoon; роботи з готовими шаблонами; вибір стилю; робота зі сценою та анімованими персонажами; вставка тексту, відео, аудіо тощо; робота зі шкалою часу; розміщення відео-презентації на YouTube.

Наступна тема пов'язана з блоком візуалізації - це особливості створення ментальних карт та інтерактивних плакатів засобами хмарних сервісів.

Вчений О. Романовський зазначає, що ментальні карти дозволяють систематизувати знання студентів (учнів), зауважує на доцільності їх використання в різних видах організації навчального процесу закладу освіти як для суб'єктів навчання, так і для викладачів (учителів). Якщо студент (учень) переважно опрацьовує інорормацію, подану викладачем (учителем) на лекції (уроці) або здобуту способом самостійного дослідницького пошуку, то створені ним ментальні карти є продуктом остаточного систематизованого матеріалу. Інформація, представлена у вигляді ментальної карти, дозволяє педагогу викладати лекцію (урок) без жорсткої прив'язки до тексту, водночас цілісний план інфрормації завжди перед очима [8].

Ментальні карти можна створювати власноруч або за допомогою програмних засобів. Під час вивчення теми надається класифікація програмних засобів, таких як Freemind, Mindmaster, Mindomo. Однак одним 3 найбільш зручних програмних засобів для створення інтелект-карт, який ми пропонуємо під час вивчення теми, - це хмарний сервіс корпорації Google застосунок www. coggle.it. Цей сервіс включає в себе досить яскраву візуалізацію, безкоштовне використання у ментальній карті посилань, зображень тощо. Досить корисна можливість працювати у команді, що можна використати під час проєктної діяльності. Зручні способи публікації ментальної карти, отримання посилання або збереження як картинки. Необмежена кількість публічних ментальних карт, що робить застосунок майже безкоштовним.

Використання інтерактивних плакатів у навчальному процесі сприяє тому, що учні краще сприймають матеріал, підвищується інтерес до предмета, підвищується ефективність їх самостійної роботи та впливає на якість фрормування практичних умінь і навичок. Плакати фрормують уміння самостійно працювати 3 джерелами інформації, дають змогу учню бачити результат та оцінку своєї праці, можливість знайти правильну відповідь, поглибити знання. Інтерактивний плакат представляє собою електронний навчальний плакат, що має інтерактивну навігацію, яка дозволяє відобразити необхідну інфрормацію: графріку, текст, звук. До особливостей інтерактивних плакатів 
відносять високу інтерактивність, простоту у використанні, великий візуальний матеріал, груповий та індивідуальний підхід [9].

Під час вивчення цієї теми ми пропонуємо майбутнім учителям створювати інтерактивні плакати засобами хмарного сервісу www.thinglink.com. Цей хмарний сервіс дозволяє брати будь-яку тематичну картинку та створювати на ній інтерактивні теги, натискання або наведення на які призводять до появи контенту текстового фрормату, віедоформату, посилання на сторонні ресурси. Таким чином, з цих тегів фрормується логічний шлях, що дозволяє побудувати цілісну картину. Також ми пропонуємо допрацювати раніше створену інтелект-карту і зробити її інтерактивною.

Далі ми працювали з використанням сервісів Web 2.0 для створення дидактичних інтерактивних матеріалів та комп'ютерних засобів контролю знань.

Суть інтерактивного навчання у тому, що навчальний процес відбувається за умови постійної, активної взаємодії всіх учнів. Це співнавчання, взаємонавчання (колективне, групове, навчання у співпраці), де і учень і вчитель $€$ рівноправними, рівнозначними суб'єктами навчання, розуміють, що вони роблять, рефлексують 3 приводу того, що вони знають, вміють і здійснюють [7]. До інтерактивних технологій можна також віднести і дидактичні ігри, такі як кросворди, вікторини тощо.

Кросворди у системі дидактичних ігор займають особливе місце. При роботі з кросвордами учні змагаються більше 3 «собою», тобто змагаються риси характеру такі як працездатність з лінню, допитливість з байдужістю, розумове напруження і посидючість з розслабленням тощо. Навчальна роль кросвордів полягає в тому, що дозволяє в ігровій ситуації інтенсифікувати процес засвоєння нових знань, а позитивні емоції, що виникають у дітей сприяють попередженню перевантаження, забезпечують фрормування комунікативних та інтелектуальних умінь. Розвиваюча і організуюча роль кросвордів полягає в тому, що при їх вирішенні учням доводиться без примусу працювати 3 підручниками, посібниками, словниками [4].

Для створення кросвордів ми пропонували майбутнім учителям використовувати генератор кросвордів crossmaker.ru. Головними рисами цього сервісу $є$ його простота використання та безкоштовність. Для створення кросворду необхідно лише обрати кількість клітинок та увести відповіді до спеціальних полів. Після генерації створюються два документа, в одному пустий шаблон для кросворда, в іншому - заповнений. Після створення шаблонів їх можна використати будь-де: або у презентації, або заповнювати безпосередньо разом 3 дітьми у шаблоні. Також ми пропонуємо хмарний сервіс для створення ребусів rebus1.com - дуже простий сервіс, що заощаджує час. Цей сервіс автоматично генерує два типи ребусів: для дорослих та дітей, необхідно лише увести необхідне слово.

Особливу роль у дидактичних іграх займають вікторини. Використання вікторини дозволяє створити емоційно-позитивний стан учня, зняти напруженість під час контролю знань, активізувати пізнавальну активність тощо. Для створення вікторин ми пропонуємо використовувати хмарні сервіси: MyQuiz, Kahoot! ta Plickers.

Хмарний сервіс MyQuiz дає широкі можливості налаштувань вікторини, можна визначати час відповіді на запитання та пояснення, обирати способи реєстрації, визначати можливість отримання подарунків тощо. Також можна створювати різні типи запитань: відкриті, з варіантами відповідей, прапорці, вставляти картинки замість запитань або разом з ними. Також у сервіс додали новий тип запитання, де відповідь необхідно намалювати. Хмарний сервіс Kahoot! працює за схожим принципом, але має інший інтерфейс, він більш яскравий та пристосований для шкільного середовища, має менше налаштувань, ніж MyQuiz, і не дає можливість намалювати відповідь. Головною рисою $є$ те, що сервіс пристосований для будь-яких гаджетів, зручно грати навіть з телеорона, що дає можливість використовувати його навіть у класах, не оснащених комп'ютерною технікою. Хмарний сервіс Plickers також має схожі налаштування, але головною особливістю $\epsilon$, те що його можна використовувати без гаджетів: достатньо телефона вчителя та надрукованих карток c QR-кодами для учнів. Всі ці особливості вивчалися під час опрацювання теми та фрормувалися вміння створювати свої власні дидактичні наробки запропонованими хмарними сервісами.

Окремими напрямами, які стали необхідними під час дистанційної освіти, стали організація збору даних у мережах, створення вебінарів та аудіо- та відеокліпів навчального призначення.

Тема «Організація збору даних у мережах (Опитування та тестування за допомогою Google Форм)» передбачала вивчення особливостей створення опитування, анкет, тестів; особливості дизайну форми; додавання зображення та відео; управління відповідями та коментарями; збереження email pecпондентів для розсилки; створення посилання для проходження фрорми; реєстрація на захід і відгук про нього; спільна робота з іншими користувачами Google Drive; автоматизація обробки результатів за допомогою додатка Floobaru.

Особливо актуальним напрямом зараз є створення вебінарів. Під час вивчення цієї теми вивчається, що таке вебінар, види та моделі вебінарів, технологічне оснащення для проведення вебінарів та сервіси для проведення вебінарів. Окрім сервісів для проведення онлайн-вебінарів, ми пропонуємо використовувати також і сервіси для 
запису та редагування вебінарів, одним 3 таких $€$ рекордер екрану FlashBack Pro, це платне програмне забезпечення, але дає сім днів на безкоштовне ознайомлення. На нашу думку, важливо робити навчальний контент 3 можливістю покадрового редагування, додавання ефектів у потрібному кадрі, можливістю склеювати різні записи тощо. Це робить продукт більш якісним, але забирає набагато більше часу.

Вивчення особливостей створення аудіо- та відеокліпів навчального призначення також $€$ актуальним питанням сьогодення. Під час вивчення цієї теми вивчаються аудіо- та відеоредактори, їх класифікація та можливості. Завданням було створення цілісного відео зі спеціальності 3 нарізок відеороликів, які є у вільному доступі у мережі. Під час роботи майбутні вчителі знайомилися 3 можливістю нарізки відео, роботою із звуковою доріжкою та заміною її на власну, налаштуванням переходів, титрів тощо.

Останньою темою було вивчення особливостей створення та офрормлення блогу у мережі Інтернет. Майбутні вчителі знайомилися 3 особливостями розміщення публікацій; створення сторінок, налаштування списку сторінок; роботою з темами та макетами; редагуванням позиціонуванням об'єктів у блозі; додаванням у блог відео, опитувань, презентацій, малюнків; використання панелі HTML редагування. Після чого створювався свій блог, та всі дидактичні наробки, які були створені з попередніх темах, завантажувалися у власний блог, на основі якого можна буде зробити у майбутньому власний блог учителя.

Висновки. Проаналізувавши наукову літературу, освітні програми та побажання вчителів, нами було розроблено робочу програму, яка включала в себе вивчення актуальних програмних засобів створення дидактичних матеріалів для майбутніх учителів, які є доступними та в більшості випадків безкоштовними. Робоча програма використовувалась під час вивчення інформатичних дисциплін на різних фракультетах з урахуванням специфріки, а також під час підвищення кваліфікації для вчителів. Після закінчення курсу у майбутніх вчителів було портфоліо, яке розміщувалося у блозі зі всіма наробками. Також проводилося опитування про необхідність вивчення цих сервісів, та які ще сервіси є цікавими та необхідними, які не увійшли в програму.

Перспективи подальших наукових розвідок полягають у дослідженні перспективних сервісів для подальшого удосконалення підготовки майбутніх учителів до використання інформаційнокомунікаційних технологій у освітньому процесі.

\section{БІБЛІОГРАФІЧНИЙ СПИСОК:}

1. Белоусова Л.И., Житенева Н.В. Дидактические аспекты использования технологий визуализации в учебном процессе общеобразовательной школы Інформаційні технології $і$ засоби навчання. Київ, 2014. Tом 40 (№ 2). C. 1-13.

2. Білоусова Л.І., Житєньова Н.В. Візуалізація навчального матеріалу 3 використанням технології скрайбінг у професійній діяльності вчителя. Фізикоматематична освіта: науковий журнал. Суми, 2016. Випуск 1(7). С. 39-47.

3. Бондаренко Т. В. Особливості використання програмного засобу Prezi у процесі розробки навчальних презентацій. Інфрормаційні технології $i$ засоби навчання. Київ, 2018, Том 63 (№ 1). С. 1-11.

4. Левицький В.Е. Особливості використання дидактичних ігор на уроках читання у молодших класах 3 метою активізації пізнавальних інтересів дітей з порушеннями розумового розвитку. Актуальні питання корекційної освіти. Київ, 2020. Вип. № 16 (том 2). С. 123-130.

5. Морзе Н.В. Як навчати вчителів, щоб комп'ютерні технології перестали бути дивом у навчанні? Комп'ютер у школі та сім'ї. Київ, 2010. № 6 (86). C. 10-14.

6. Мотилькова 3.О. ІКТ-компетентність вчителяпредметника, як необхідна складова в сучасній спеціальній школі. Інформаційні технології $і$ засоби навчання. Київ, 2014. Том 44. № 6. С. 57-71.

7. Пометун О.І., Пироженко Л.В. Сучасний урок. Інтерактивні технології навчання: Науково-методичний посібник. Київ : А.С.К., 2004. 192 с.

8. Романовський О.Г. Ментальні карти як інноваційний спосіб організації інфрормації в навчальному процесі вищої школи. Інформаційні технології $i$ засоби навчання. Київ, 2018. Т. 64, № 2. С. 185-196.

9. Шахіна І.Ю. Інтерактивні плакати в освітній діяльності. Проблеми та перспективи фрормування національної гуманітарно-технічної еліти. Харків : НТУ «ХП|», 2015. Вип. 42 (46). С. 403-412.

10. Шахіна І. Створення інфрографріки за допомогою сучасних Інтернет-сервісів. Наукові записки. Серія: Проблеми методики фрізикоматематичної $і$ технологічної освіти. Кіровоград, 2015. Вип. 8, ч. 2. C. 58-64.

11. Шишкіна М.П., Попель М.В. Хмаро орієнтоване освітнє середовище навчального закладу: сучасний стан і перспективи розвитку досліджень. Інформаційні технології $і$ засоби навчання. Київ, 2013. № 5 (37). C. $66-80$. 